\title{
Pemahaman Dan Penerapan Hukum Tentang Desain Tata Letak Sirkuit Terpadu Nenni
}

155100053, 785567849

Fakultas Komputer

neni.student@umitra.ac.id

\begin{abstract}
Saat ini, ada tujuh objek Hak Kekayaan Intelektual (HKI) di Indonesia yang sudah dilindungi oleh hukum. Satu diantaranya adalah Desain Tata Letak Sirkuit Terpadu (DTLST). Di dalam sistem hukum HKI, DTLST relatif masih baru. Bahkan, saat ini pun masih banyak masyarakat Indonesia yang belum mengetahui secara pasti apa yang dimaksud dengan DTLST.Bagaimana penerapan Undang-Undang No. 32 tahun 2000 Tentang Desain Tata Letak Sirkuit Terpadu di Indonesia? Apa obyek dan apa peran DTLST dalam sistem hukum HKI ? Hal ini dapat dimengerti karena undang-undang tentang DTLST baru diundangkan tahun 2000 bersama dengan tiga undang-undang HKI lainnya, yaitu Undang-Undang No. 29 tahun 2000 Tentang Perlindungan Varietas Tanaman; Undang-Undang No. 30 tahun 2000 Tentang Rahasia Dagang; Undang-Undang No. 31 tahun 2000 Tentang Desain Industri; dan Undang-Undang No. 32 tahun 2000 Tentang Desain Tata Letak Sirkuit Terpadu.

Undang-undang ini dilahirkan sebagai konsekuensi dari ditandatanganinya persetujuan akhir (Final Act) Putaran Uruguay, yang salah satu hasil perundingannya adalah dibentuknya lembaga perdagangan dunia yang dikenal dengan World Trade Organization (WTO). Persetujuan pembentukan lembaga WTO itu kemudian diratifikasi[ii] Indonesia dengan Undang-Undang No. 7 Tahun 1994 tentang Pengesahan Agreement Establising the World Trade Organization (Persetujuan Pembentukan Organisasi Perdagangan Dunia). Setiap anggota WTO wajib meratifikasi seluruh keputusan lembaga ini termasuk Trade Related Aspect of Intellectual Property Rights(TRIPs) Agreement, atau persetujuan tentang aspek-aspek perdagangan Hak Kekayaan Intelektual yang mengacu pada landasan perlindungan DTLST yaitu Treaty on Intellectual Property in Respect of Integrated Circuits (Washington Treaty). Namun, tentang Desain Tata Letak Sirkuit Terpadu setiap negara angota diberi kebebasan untuk mengatur sendiri dan menyesuaikan dengan keadaan lingkungan serta kemajuan teknologi dalam negeri yang bersangkutan.
\end{abstract}

Kata Kunci : Hak Kekayaan Intelektual 


\section{A. INTRODUCTION}

Abad 21 adalah era teknologi terutama teknologi komunikasi. Apa artinya? Pada abad ini banyak invensi (temuantemuan) di bidang teknologi yang sangat mengagumkan. Manusia dengan alat komunikasi, misalnya HP (hand phone) dapat mengatasi kebutuhan ruang dan waktu. Ruang dan waktu bukanlah kendala lagi bagi manusia untuk mencapai maksud dan tujuan hidupnya. Ruang dapat dipersempit terutama jarak, dan waktu dapat dipersingkat dengan teknologi super canggih itu. Temuan-temuan di bidang teknologi ini menjadi dasar kemajuan dunia industri. Salah satu komponen penting dari produk-produk industri berteknologi tinggi adalah Circuit Housed in a Platform (CHIP)[i]. $\quad$ CHIP merupakan kumpulan dari sejumlah transistor, diode dan kapasitor, yakni unsur-unsur penghubung atau pengubah arus listrik. yang memungkinkan aliran-aliran listrik yang menjadi penggerak sarana elektronika (Tim Lindsey, et al, 2002, hlm 226). Peletakan CHIP dalam satu kesatuan tidak dapat dilakukan oleh sembarang orang yang bukan ahli. Karena para inventor itu adalah tenaga profesional dengan latar belakang pendidikan khusus, maka hasil invensinya perlu dan harus dilindungi oleh hukum.

Saat ini, ada tujuh objek Hak Kekayaan Intelektual (HKI) di Indonesia yang sudah dilindungi oleh hukum. Satu diantaranya adalah Desain Tata Letak Sirkuit Terpadu (DTLST). Di dalam sistem hukum HKI, DTLST relatif masih baru. Bahkan, saat ini pun masih banyak masyarakat Indonesia yang belum mengetahui secara pasti apa yang dimaksud dengan DTLST.Bagaimana penerapan Undang-Undang No. 32 tahun 2000 Tentang Desain Tata Letak Sirkuit Terpadu di Indonesia? Apa obyek dan apa peran DTLST dalam sistem hukum HKI ? Hal ini dapat dimengerti karena undangundang tentang DTLST baru diundangkan tahun 2000 bersama dengan tiga undangundang HKI lainnya, yaitu Undang-Undang No. 29 tahun 2000 Tentang Perlindungan Varietas Tanaman; UndangUndang No. 30 tahun 2000 Tentang Rahasia Dagang; Undang-Undang No. 31 tahun 2000 Tentang Desain Industri; dan Undang-Undang No. 32 tahun 2000 Tentang Desain Tata Letak Sirkuit Terpadu. Undang-undang ini dilahirkan sebagai konsekuensi dari ditandatanganinya persetujuan akhir (Final Act) Putaran Uruguay, yang salah satu hasil perundingannya adalah dibentuknya lembaga perdagangan dunia yang 
dikenal dengan World Trade Organization (WTO).

Persetujuan pembentukan lembaga WTO itu kemudian diratifikasi[ii] Indonesia dengan Undang-Undang No. 7 Tahun 1994 tentang Pengesahan Agreement Establising the World Trade Organization (Persetujuan Pembentukan Organisasi Perdagangan Dunia). Setiap anggota WTO wajib meratifikasi seluruh keputusan lembaga ini termasuk Trade Related Aspect of Intellectual Property

Rights(TRIPs) Agreement, atau persetujuan tentang aspekaspek perdagangan Hak Kekayaan Intelektual yang mengacu pada landasan perlindungan DTLST yaitu Treaty on Intellectual Property in Respect of Integrated Circuits (Washington Treaty). Namun, tentang Desain Tata Letak Sirkuit Terpadu setiap negara angota diberi kebebasan untuk mengatur sendiri dan menyesuaikan dengan keadaan lingkungan serta kemajuan teknologi dalam negeri yang bersangkutan.

\section{B. CONTEN}

1. Istilah dan Konsep Sistem Perlindungan DTLST

Di beberapa negara maju mempunyai istilah Disain Tata Letak Sirkuit yang berbeda. Sebagai contoh misalnya Amerika Serikat menyebut Semiconductor Chip; Australia menyebut Circuit Layout atau
Integrated Circuit, dan Eropa menyebut Silicon Chips; TRIPs Agreement menyebutkan sebagai Layout Design (Topographies) of Integrated Circuit dan Indonesia sendiri menyebut Desain Tata Letak Sirkuit Terpadu (DTLST). Perlindungan hak atas DTLST dapat diberikan oleh negara melalui Departemen Hukum dan HAM c.q. Direktorat Jenderal Hak Kekayaan Intelektual apabila diminta dengan permohonan oleh pendesain atau badan hukum yang berhak atas desain tersebut.

\section{Definis i}

Berdasarkan ketentuan dalam Pasal 1 ayat (1 ) dan (2) Undang-Undang No. 32 Tahun 2000 tentang Desain Tata Letak Sirkuit Terpadu tentang ini dapat dipahami dua hal yaitu Sirkuit Terpadu dan Desain Tata Letak.

a. Sirkuit Terpadu didefinisikan sebagai suatu produk dalam

"bentuk jadi atau setengah jadi yang didalamnya terdapat berbagai elemen dan sekurang-kurangnya satu dari elemen tersebut adalah elemen aktif yang sebagian atau seluruhnya saling berkaitan serta dibentuk secara terpadu didalam sebuah bahan semi konduktor yang dimaksudkan untuk menghasilkan fungsi elektronik”.

Sirkuit Terpadu terpadu yang dimaksud di sini adalah yang dalam bentuk jadi dan setengah jadi dengan pertimbangan yang setengah jadi sudah dapat berfungsi secara elektronis juga. Motherboard komputer merupakan contoh sirkuit terpadu. 
b. Yang dimaksud dengan Desain Tata Letak adalah :

"kreasi berupa rancangan peletakan tiga dimensi dari berbagai elemen, sekurang-kurangnya satu dari elemen tersebut adalah elemen aktif serta sebagaian atau semua interkoneksi dalam suatu sirkuit terpadu dan peletakan tiga dimensi tersebut dimaksudkan untuk persiapan pembuatan sirkuit terpadu".

Desain tata letak yang dimaksud adalah pola atau seni peletakan berbagi elemen di atas suatu bahan sehingga menjadi suatu sirkuit terpadu.

\section{Ruang Lingkup}

\section{a. Subyek DTLST}

Penemu desain tata letak sirkuit terpadu disebut pendesain. Pendesain adalah seorang atau beberapa orang yang menghasilkan Desain Tata Letak Sirkuit Terpadu. Hak Desain Tata Letak Sirkuit Terpadu adalah hak ekslusif yang diberikan oleh negara kepada pendesain atas hasil kreasinya untuk selama waktu tertentu melaksanakan sendiri, atau memberikan persetujuan kepada pihak lain untuk melaksanakan hak tsb. Dengan demikian yang memperoleh hak atas suatu desain selain pendesain adalah yang menerima hak tersebut dari pendesain. Yang berhak memperoleh hak DTLST adalah pendesain, atau beberapa pendesain dalam hal bekerja bersama (Pasal 5). Pasal 6 menjelaskan bahwa yang dalam hal hubungan dinas yaitu pegawai negeri dan instansi terkait adalah instansi yang bersangkutan. Hal ini dimaksudkan agar suatu desain yang dibuat berdasarkan pesanan, misalnya instansi pemerintah, tetap dipegang oleh instansinya selaku pemesan, kecuali diperjanjikan lain. Ketentuan ini itidak mengurangi hak pendesain untuk mengkalim haknya apabila DTLST digunakan untuk halhak di luar hubungan kedinasan tersebut. Bila DTLST dibuat atas hubungan kerja, yaitu hubungan di lingkungan swasta, atau hubungan individu dengan pendesain, orang yang membuat adalah pendesain dan pemegang hak, kecuali diperjanjikan lain.

\section{b. Obyek DTLS}

Obyek DTLST yang dilindungi adalah yang orisinial. Yang dimaksud dengan orisinal adalah apabila desain tersebut merupakan hasil karya pendesain itu sendiri dan bukan merupakan tiruan dari hasil karya pendesain lain. Artinya desain tersebut merupakan hasil karya mandiri pendesain. Dan, pada saat desain itu dibuat bukan merupakan hal yang umum bagi para pendesain. Selain orisinal desain itu harus mempunyai nilai ekonomis dan dapat diterapkan dalam dunia industri secara komersial.

\section{c. Hak Eksklusif Dan Hak Moral}

Hak DTLST diberikan atas dasar Permohonan (Pasal 9). Hak eksklusif yang dipegang adalah untuk melaksanakan hak tersebut sendiri (Pasal 8 ayat (1) dan dapat :

1) melarang orang lain untuk tanpa persetujuannya membuat, memakai, menjual, mengimport, mengeksport, dan atau 
2) mengedarkan barang yang didalamnya terdapat seluruh atau sebagian desain yang telah diberi Hak Desain Tata Letak Sirkuit Terpadu,

3) kecuali untuk kepentingan penelitian dan pendidikan sepanjang tidak merugikan kepentingan pemegang Hak Desain Tata Letak Sirkuit Terpadu tsb.

Hak moral seorang pendesain adalah hak pencantuman nama pendesain dalam sertifikat, Daftar Umum, Berita Resmi DTLST, sekalipun hak ekonominya sudah dialihkan seluruh atau sebagian kepada pihak lain.

\section{Waktu Perlindungan DTLST}

Perlindungan hak yang diberikan kepada pendesain Tata Letak Sirkuit Terpadu adalah selama 10 tahun (Pasal 4 ayat (3) dihitung dari sejak pertama kali desain itu dieksploitasi secara komersial dimanapun sejak tanggal penerimaan (Pasal 4 Ayat (1). Jangka waktu perlindungan yang singkat karena perkembangan teknologi yang begitu cepat, sehingga waktu 10 tahun dianggap cukup memadai. Dalam hal desain telah dieksploitasi secara komersial permohonan harus diajukan paling lambat 2 (dua) tahun terhitung sejak tanggal dieksploitasi. Jika waktu perlindungan sudah selesai, jangka waktu tersebut tidak dapat diperpanjang lagi dan konsekuensinya desain tersebut menjadi milik umum (public domein). Siapa pun boleh mengunakan desain tersebut.

\section{Pengalihan Hak Dan Lisensi}

Hak DTLST adalah hak eksklusif yang diberikan negara jepada pendesain atas hasil kreasinya, yang untuk waktu tertentu melaksanakan sendiri atau memberikan persetujuan kepada pihak lain untuk melaksanakan hak tersebut. Dengan demikian pengalihan hak adalah dimungkinkan. Perlu diketahui bahwa pengalihan hak tidak menghilangkan hak pendesain untuk tetap dicantumkan nama dan identitasnya, baik dalam sertifikat, berita resmi maupun daftar umum.

Ada beberapa cara pengalihan yang diketahui, yaitu:

a. Pengalihan Hak

Pengalihan HDTLST harus disertai dengan dokumen pengalihan hak dan dicatat pada Daftar Umum Hak DTST. Seperti HKI lainnya Hak Desain Tata Letak Sirkuit Terpadu dapat beralih atau dialihkan dengan:

1) Pewarisan

2) Hibah

3) wasiat

4) Perjanjian tertulis atau

Sebab-sebab lain yang dibenarkan oleh peraturan perundang- undangan.

b. Lisensi

Hak atas DTLST selain dapat dialihkan dengan cara di atas, dapat juga dialihkan dengan perjanjian lisensi. Pemegang Hak pemberi lisensi tetap dapat melaksanakan sendiri haknya dan tetap dapat memberi lisensi pada pihak lain kecuali diperjanjikan lain. Perjanjian lisensi 
harus dibuat secara tertulis dan tidak boleh memuat ketentuan yang dapat merugikan perekonomian Indonesia atau mengakibatkan persaingan usaha yang tidak sehat sebagaimana diatur dalam peraturan per-undang undangan yang berlaku. Perjanjian lisensi seperti perjanjian pengalihan hak wajib didaftarkan pada DTLST. Perjanjian lisensi yang tidak didaftar tidak mempunyai akibat hukum terhadap pihak ketiga.

\section{Pendaftaran Permohonan DTLST} Dan Pembatalan

DTLST dilindungi bila didaftarkan. Hal pendaftaran diatur di dalam Pasal 9 sampai dengan Pasal 28 UndangUndang No. 32 Tahun 2000 tentang DTLST. Pendaftaran dilakukan dengan permohonan. Pada prinsipnya permohonan dapat dilakukan sendiri oleh pemohon. Khusus, untuk pemohon yang bertemnpat tinggal di luar Indonesia, permohonan harus diajukan melalui kuasa. Hak ini untuk mempermudah pemohon yang bersangkutan, antara lain mengingat dokumen permohonan seluruhnya menggunakan bahasa Indonesia. Di samping itu, domisili pemohon harus di Indonesia. Dengan demikian syarat ini dapat diatasi dengan adanya kuasa hukum dari Indonesia. Permohonan hanya untuk satu desain (Pasal 11). Pemohon dari luar Indonesia harus mengajukan permohonan melalui kuasa hukumnya dan memilih domisili hukum di Indonesia.

Pembatalan Pendaftaran DTLST dapat dilakukan dengan permintaan pemegang hak. Pembatalan ini hanya dapat dilakukan oleh Direktorat Jenderal atas permintaan tertulis pemegang hak. Atau, berdasarkan gugatan. Gugatan dapat diajukan oleh pihak yang berkepentingan. Akibat pembatalan pendaftaran suatu desain mengakibatkan hapusnya segala akibat hukum yang berkaitan dengan Hak DTLST dan hak-hak lain yang berasal dari DTLST.

\section{Litigasi Dan Penyelesain Sengketa DTLST}

Pemegang hak DTLST dapat menggugat siapa saja yang dengan sengaja dan tanpa hak melanggar Pasal 8, yaitu membuat, memakai, menjual, mengimpor, mengekspor dan atau mengedarkan barang yang didalamnya terdapat seluruh atau sebagian desain yang telah diberikan Hak DTLST. Gugatan ditujukan kepada Pengadilan Niaga (Pasal 38). Di samping itu bisa melalui arbitrase, atau alternatif penyelesaian sengketa (negosiasi, mediasi, konsiliasi), dan cara lain yang dipilih oleh para pihak.

Pelanggaran DTLST selain dapat digugat secara perdata juga tidak menutup kemungkinan untuk digugat secara pidana. Sanksi pidana terhadap pelanggaran DTLST menurut Pasal 42 ayat (1) dituntut dengan penjara paling lama tiga (3) tahun atau denda paling banyak Rp. 300.000.000,- (tiga ratus juta rupiah) Tindak pidana yang diatur dalam Undang-Undang No. 32 tahun 2000 tentang Desain Tata Letak Sirkuit 
Terpadu merupakan delik aduan.

\section{CONCLUSION}

Sejak tahun 2000 UndangUndang No. 32 tahun 2000 Tentang Desain Tata Letak Sirkuit Terpadu sudah diundangkan oleh Pemeirntah Indonesia sebagai pemenuhan suatu syarat minimum yang terdapat dalam perjanjian Trade Related Aspects of Intellectual PropertyRights (TRIPs) yang menghendaki agar setiap negara anggota WTO yang telah meratifikasi perjanjian tersebut membuat peraturan sendiri. Namun, sampai saat ini di Indonesia belum ditemukan kasus-kasus pelanggaran Desain Tata Letal Sirkuit Terpadu. Hal ini dimungkinkan karena teknologi di Indonesia belum begitu maju dibandingkan negera-negara seperti Jepang, Amerika Serikat dan negara-negara Eropa. Alih Teknologi belum berjalan dengan baik, sehingga kemampuan teknologi bangsa Indonesia belum memadai untuk mendaftarkan hak atas Desain Tata Letak Sirkuit Terpadu. Masyarakat masih diberi kesempatan untuk mencontoh dan melatih diri untuk menemukan sesuatu di bidang DTLST.

\section{DISCUSSION}

Secara institusional, pada saat ini telah ada Direktorat Jendral Hak Kekayaan Intelektual yang tugas dan fungsi utamanya adalah menyelenggarakan administrasi hak cipta paten, merek, desain industri, dan desain tata letak sirkuit terpadu. Direktorat Jenderal Hak Kekayaan Intelektual (semula disebut Direktorat Jenderal Hak Cipta, Paten dan Merek) dibentuk pada thaun 1998. Direktorat Jendral Hak Kekayaan Intelektual yang baik sebagaimana yang diharapkan oleh masyarakat, baik yang berasal dari dunia industri dan perdagangan, maupun dari institusi yang bergerak di bidang penelitian dan pengembangan.

Sejauh ini pegawai di lingkungan Direktorat Jenderal Hak Kekayaan Intelektual berjumlah 450 orang. Dibandingkan dengan yang ada di beberapa negara yang telah maju. Direktorat Jendral HaKI merupakan institusi yang relatif masih muda/naru. Oleh sebab itu, dapat dimaklumi seandainya dalam pelaksanaan tugasnya, masih dijumpai berbagai macam kendala. Walaupun demikian, melalui berbagai program pelatihan yang intensif telah ada beberapa staf yang memiliki pengetahuan yang cukup memadai guna mendukung peningkatan sistem hak kekayaan intlektual sebagaimana diharapkan

Perlu pula kiranya dikemukakan bahwa dalam rangka lebih meningkatkan pelayanan dan kemudahan bagi masyarakat, sejak januari 
2000, pengajuan permohonan hak kekayaan intelektual dapat dilakukan di Kantor-kantor Wilayah Departemen Kehakiman dan Hak Asasi Manusia

Selanjutnya, Kantor-kantor Wilayah akan menyampaikan permohonan tersebut kepada Direktorat Jenderal HaKI untuk diproses ebih lanjut. Di samping itu, pada saat ini, dengan bantuan World Bank sedang dilaksanakan penyempurnaan sistem otomasi di Direktorat Jenderal HaKI yang diharapkan dapat lebih menunjang proses administrasi dimaksud. Tidak sebagaimana bidang kekayaan intelektual lain yang administrasinya dikelola oleh Direktorat Jenderal HaKI, bidang varietas tanaman ditangani oleh Departemen Pertanian

\section{E. REFERENCE}

[1] O. M. Febriani and A. S. Putra, "Sistem Informasi Monitoring Inventori Barang Pada Balai Riset Standardisasi Industri Bandar Lampung," J. Inform., vol. 13, no. 1, pp. 90-98, 2014.

[2] A. S. Putra, "Paperplain: Execution Fundamental Create Application With Borland Delphi 7.0 University Of Mitra Indonesia," 2018.

[3] A. S. Putra, "2018 Artikel
Struktur Data, Audit Dan Jaringan Komputer," 2018.

[4] A. S. Putra, "ALIAS MANAGER USED IN DATABASE DESKTOP STUDI CASE DB DEMOS."

[5] A. S. Putra, "COMPREHENSIVE SET OF PROFESSIONAL FOR DISTRIBUTE COMPUTING."

[6] A. S. Putra, "DATA ORIENTED RECOGNITION IN BORLAND DELPHI 7.0."

[7] A. S. Putra, "EMBARCADERO DELPHI XE 2 IN GPUPOWERED FIREMONKEY APPLICATION."

[8] A. S. Putra, "HAK ATAS KEKAYAAN INTELEKTUAL DALAM DUNIA TEKNOLOGY BERBASIS REVOLUSI INDUSTRI 4.0."

[9] A. S. Putra, "IMPLEMENTASI PERATURAN

PERUNDANGAN UU. NO 31 TAHUN 2000 TENTANG DESAIN INDUSTRI BERBASIS INFORMATION TECHNOLOGY."

[10] A. S. Putra, "IMPLEMENTATION OF PARADOX DBASE."

[11] A. S. Putra, "IMPLEMENTATION OF TRADE SECRET CASE STUDY SAMSUNG MOBILE PHONE."

[12] A. S. Putra, "IMPLEMENTATION PATENT FOR APPLICATION WEB BASED CASE STUDI WWW. PUBLIKLAMPUNG. COM."

[13] 
SYSTEM FIRST TO INVENT IN DIGITALLY INDUSTRY."

[14] A. S. Putra, "MANUAL REPORT \& INTEGRATED DEVELOPMENT

ENVIRONMENT BORLAND DELPHI 7.0."

[15] A. S. Putra, "PATENT AS RELEVAN SUPPORT RESEARCH."

[16] A. S. Putra, "PATENT FOR RESEARCH STUDY CASE OF APPLE. Inc."

[17] A. S. Putra, "PATENT PROTECTION FOR APPLICATION INVENT."

[18] A. S. Putra, "QUICK REPORT IN PROPERTY PROGRAMMING."

[19] A. S. Putra, "REVIEW CIRCUIT LAYOUT COMPONENT

REQUIREMENT ON ASUS NOTEBOOK."

[20] A. S. Putra, "REVIEW TRADEMARK PATENT FOR INDUSTRIAL TECHNOLOGY BASED 4.0."

[21] A. S. Putra, "TOOLBAR COMPONENT PALLETTE IN OBJECT ORIENTED PROGRAMMING."

[22] A. S. Putra, "WORKING DIRECTORY SET FOR PARADOX 7."

[23] A. S. Putra, "ZQUERY CONNECTION

IMPLEMENTED

PROGRAMMING

STUDI CASE PT. BANK BCA Tbk."

[24] A. S. Putra, D. R. Aryanti, and I. Hartati, "Metode SAW (Simple Additive Weighting) sebagai Sistem Pendukung Keputusan Guru Berprestasi
(Studi Kasus: SMK Global Surya)," in Prosiding Seminar Nasional Darmajaya, 2018, vol. 1, no. 1, pp. 85-97.

[25] A. S. Putra and O. M. Febriani, "Knowledge Management Online Application in PDAM Lampung Province," in Prosiding International conference on Information Technology and Business (ICITB), 2018, pp. 181-187.

[26] A. S. Putra, O. M. Febriani, and B. Bachry, "Implementasi Genetic Fuzzy System Untuk Mengidentifikasi Hasil Curian Kendaraan Bermotor Di Polda Lampung," SIMADA (Jurnal Sist. Inf. dan Manaj. Basis Data), vol. 1, no. 1, pp. 21-30, 2018.

[27] A. S. Putra, H. Sukri, and K. Zuhri, "Sistem Monitoring Realtime Jaringan Irigasi Desa (JIDES) Dengan Konsep Jaringan Sensor Nirkabel," IJEIS (Indonesian J. Electron. Instrum. Syst., vol. 8, no. 2, pp. 221-232.

[28] D. P. Sari, O. M. Febriani, and A. S. Putra, "Perancangan Sistem Informasi SDM Berprestasi pada SD Global Surya," in Prosiding Seminar Nasional Darmajaya, 2018, vol. 1, no. 1, pp. 289-294. 